Artigo Original

Hegemonia - Revista Eletrônica do Programa de Mestrado em Direitos Humanos, Cidadania e

Violência/Ciência Política do Centro Universitário Unieuro

ISSN: 1809-1261

UNIEURO, Brasília, número 27 (Especial), 2019, pp. 245-264.

Recebido em: 16/9/2018

Avaliado em: 28/10/2018

Aprovado em: 21/11/2018

\title{
O NASCIMENTO DA ARTE DA CIÊNCIA POLÍTICA
}

\author{
Ângelo Roberto Rosa Ávila ${ }^{1}$ e Vicente Fonseca ${ }^{2}$
}

Resumo: O objetivo do presente artigo é mostrar como nasceu a arte da Ciência Política, através do seu grande artífice Nicolau Maquiavel, que mesmo ao passar séculos este pensamento se mantém contemporâneo. Procurando colocar nesse escrito, toda a riqueza e diversidade de pensamento desse ilustre florentino, que mantem as ideias a respeito das leis, a liberdade, as instruções políticas, o proclame entre a ética e a política e a necessidade de se distinguir a ação moral da ação política propriamente dita. As ideias de Maquiavel serão mostradas numa visão de uma Itália dividida entre a república e o principado, e sobre esse aspecto vamos ver algumas colocações dele a respeito de suas três grandes obras: a principal "O Príncipe”, depois Comentários sobre a Primeira Década de Tito Lívio (os Discorsi) e A Arte da Guerra e ao mesmo tempo mostrar qual a sua visão do que é um "Estado" (república ou monarquia). Dentro desses pensamentos, vamos procurar mostrar suas colocações políticas.

Palavras-Chaves: Maquiavel; ética; política; Estado; República (res pública); Principado; virtú.

Abstract: The aim of this paper is to show how was born the Political Science Art, through your great thinker Niccolo Machiavelli can be cross centuries and even today as a philosopher with contemporary conceptions . Looking to put in writing all the richness and diversity of thought that illustrious Florentine, keeping the ideas about the laws, freedom, the political instructions, to proclaim between ethics and politics and the need to distinguish the moral action of political action itself. Machiavelli 's ideas are shown a vision of an Italy divided between the Republic and the government, and on this point we will see some settings to it regarding its three major works : the main " The Prince " after comments on the First Decade of Titus Livy ( the Discourses) and the Art of War while showing what is your view of what a " state" ( monarchy or republic). Within these thoughts, we seek to show their placement policies.

Key-Words: Machiavelli, ethics, politics, state, republic (res publica) ; Principality ; virtu .

\footnotetext{
${ }^{1}$ Mestre em Ciência Política pelo Centro Universitário UNIEURO; Bacharel e Licenciado em Ciências Biológicas pela USU/RJ; Especialista em Educação Ambiental pela UCB/DF.

${ }^{2}$ Pósdoutorando pela University of London e Doutor e Mestre em Ciência Política pelo Departamento de Ciência Política e Relações Internacionais da Universidade de Paris 1.
} 
Artigo Original

Hegemonia - Revista Eletrônica do Programa de Mestrado em Direitos Humanos, Cidadania e Violência/Ciência Política do Centro Universitário Unieuro

ISSN: 1809-1261

UNIEURO, Brasília, número 27 (Especial), 2019, pp. 245-264.

INTRODUÇÃO

Afirmamos com muita segurança que a Ciência Política tem como artífice Niccolò Machiavelli (1469 - 1527) que não apenas escreveu sobre a política, mas participou intensamente da vida política de seu tempo. Nasceu em Florença a 3 de maio de 1469, vinha de uma antiga família da Toscana remota do antigo século XII. Em 1494 Maquiavel foi copista de Marcelo Virgílio Adriani ${ }^{3}$, professor de literatura grega e latina, secretário da República de Florença. Aos 29 anos foi nomeado chanceler, secretário dos Dez Magistrados da Liberdade e da Paz, constituía o governo da república. Pouco influente politicamente só executava as ordens do governo Dos Dez, dessa forma foi importante para o seu papel político como escritor. Foi assessor do Duque Cesar Bórgia ${ }^{4}$ (1502) para tratar de documentos no governo de Florença.

Mesmo sem ter muitas mudanças em suas ações dentro do governo de Florença, Maquiavel estreita suas relações com o Duque Valentino onde foi importante para ele o desenvolvimento de seus pensamentos e a ligação com a Romanha decidiu o seu destino como cientista e escritor político. Além dos deveres do cargo, de estudos históricos, poesia e da organização política e militar da república florentina, em 1505 concebia o projeto de milícia nacional para substituir as tropas mercenárias.

Entre 1498 e 1512, exerceu um cargo importante na administração da República de Florença como secretário do Conselho dos Dez da Guerra, a instituição que tratava da guerra e da diplomacia. Esse foi o período em que os Médici, uma família poderosíssima e muito influente nos negócios da república florentina ao longo da juventude de Maquiavel, estiveram temporariamente afastados da administração pública. Foi só com o retorno dos Médici ao poder, em 1512 quando Maquiavel foi afastado da administração pública, que ele se tornou um escritor político.

Seus principais escritos são O Príncipe, de 1513, os Discursos sobre a Primeira Década de Tito Livio, cuja redação inicia no mesmo ano é a história de Florença escrita a partir de 1520 e A Arte da Guerra (1519-1520), quando, tendo sido os Médici afastados novamente do poder, Maquiavel

\footnotetext{
${ }^{3}$ Foi humanista e político italiano, professor do Studio Fiorentino de 1494 a 1503, desde 1498 chanceler da Signoria de Florença.

4 Cesare Borgia, Duca Valentino em italiano. Foi um príncipe, cardeal e nobre italiano da Renascença europeia.
} 
Artigo Original

Hegemonia - Revista Eletrônica do Programa de Mestrado em Direitos Humanos, Cidadania e Violência/Ciência Política do Centro Universitário Unieuro

ISSN: 1809-1261

UNIEURO, Brasília, número 27 (Especial), 2019, pp. 245-264.

consegue retornara à vida, não mais num cargo executivo como esperava, mas historiador oficial da República.

Esse foi o período politicamente muito conturbado, na Itália, então dividida em várias pequenas repúblicas e principados, que disputavam o poder entre si e frequentemente se invadiam mutuamente, muitas vezes com a ajuda de forças estrangeiras, como as da França e da Espanha. Durante o Renascimento, as cinco principais potências na península Itálica eram: o Ducado de Milão, a república de Veneza, a república de Florença, o Reino de Nápoles e os Estados Pontifícios. A maior parte dos Estados da península era ilegítimos, tomados por mercenários chamados "condottiere".

Assim era também como Florença no período em que Maquiavel esteve atuante nos negócios públicos, Florença esteve em guerra com Pisa, quase foi invadida por Cesar Bórgia, o filho do Papa Alexandre VI ${ }^{5}$, que havia conquistado a Romanha e exigia o retorno dos Médici, e sofria a pressão das forças francesas e espanholas. Ao longo desse período, Maquiavel viajou incessantemente, participando de 23 missões diplomáticas as cortes italianas e europeias, conhecendo vários dirigentes políticos, como Luís XII de França, o Papa Júlio II ${ }^{6}$, o Imperador Maximiliano $\mathrm{I}^{7}$ e César Bórgia, além de ter tido um importante papel na organização das milícias florentinas. A experiência política adquiriu ao longo desse período lhe serviu de base para os seus escritos políticos.

Maquiavel não apenas escreveu sobre a política a partir de uma prática. Ele escreveu também visando à prática. Ele nunca se conformou com o seu afastamento da vida pública, causando pelos vínculos que mantinha com aqueles que haviam derrubado os Médici, que conseguiriam restabelecer no poder. Ele queria contribuir efetivamente para a estabilização da vida política italiana, tomar parte das decisões, participar e agir. Com esse intuito escreveu O Principe e o dedicou a Lourenço de Médici, um membro da família que, naquele momento, tinha o poder necessário para agir e decidir o destino não só de Florença, como também, na expectativa de Maquiavel, de toda a Itália.

\footnotetext{
5 Foi o $214^{\circ}$ papa da Igreja Católica, de 10 de Agosto 1492 até a data da sua morte. Natural de Valência, estudou na Universidade de Bolonha e adotou o nome de Rodrigo Borgia ao chegar à Itália.

6 Foi Papa de 1 de Novembro de 1503 ate à data da sua morte 21 de fevereiro de 1513. Era frade franciscano.

${ }^{7}$ Foi Sacro Imperador Romano de 1508 (de facto, a partir de 1493) até à sua morte. Foi sucedido no império por seu neto Carlos V de Habsburgo.
} 
Artigo Original

Hegemonia - Revista Eletrônica do Programa de Mestrado em Direitos Humanos, Cidadania e Violência/Ciência Política do Centro Universitário Unieuro

ISSN: 1809-1261

UNIEURO, Brasília, número 27 (Especial), 2019, pp. 245-264.

A dedicar O Príncipe a um Médici, Maquiavel visa também convencer aqueles que o havia banido da vida pública, de que, com sua experiência sobre a política, ele não merecia ter sido afastado dela.

Com uma breve discursão sobre a história que levou Maquiavel a escrever suas grandes obras, vamos descrever nos capítulos a seguir os pensamentos desenvolvidos por esse extraordinário e polêmico pensador sobre o conceito moderno de Estado.

A Arte da Ciência Politica

Conciliando sempre a política com as formas de pensamento para sua época, Maquiavel procura se manter dentro da política de Estado, onde não só Florença, mas como a própria Itália, estaria passando por momentos de grandes conturbações. Com conflitos entre repúblicas e principados e reintegração dos Médici no governo de Florença em 8 e novembro de 1502, Maquiavel foi privado de seu cargo como secretário da Senhoria e em 17 de novembro do mesmo ano o ex-secretário acabou por ser exilado da cidade.

Em 1513 descobria-se em Florença havia uma suspeita de conspiração contra o cardial Geovanni de Médici ${ }^{8}$ Maquiavel foi preso como suspeito e torturado e beneficiado, pouco tempo depois, pela anistia de Leão X, ficando exilado aos redores de Florença, com isso floresceu a sua literatura e assim começa então a descrever suas grandes obras em que até hoje são calcadas as ideias de modernidade sobre o Estado. "O Príncipe", sua grande obra, os Discurso sobre a Primeira Década de Tito Lívio, os Sete Livros sobre a Arte da Guerra, As Comédias e a Vida de Castruccio Castracani ${ }^{9}$.

Com o Cardeal Giulio de Médici no poder de Florença, Maquiavel fica com o encargo de escrever sobre a história da cidade, encarregado de inspecionar as fortificações de Florença e negociar com o governador de Romanha, Francesco Guicciardini como diplomata e seu último cargo foi uma missão junto ao Exército da Liga contra Carlos V. A partir de todos esses cargos ocupados Maquiavel pode então ter uma vasta bagagem para escrever as suas principais obras filosóficas.

\footnotetext{
${ }^{8}$ Foi eleito o cardeal Giovanni Lorenzo de' Medici, que tomou por nome Leão X. O conclave papal de 1513 deu como resultado a eleição do Papa Leão X para suceder ao Papa Júlio II, morto em 20 de fevereiro.

${ }^{9}$ Castruccio Castracani de Antelminelli (Lucca , 29 março 1281 - Lucca , 03 de setembro 1328 ) foi um líder italiano .
} 
Artigo Original

Hegemonia - Revista Eletrônica do Programa de Mestrado em Direitos Humanos, Cidadania e Violência/Ciência Política do Centro Universitário Unieuro

ISSN: 1809-1261

UNIEURO, Brasília, número 27 (Especial), 2019, pp. 245-264.

N Século XV desenvolve-se a partir da derrocada da economia feudal surgindo então o processo da ascensão do capitalismo, surgindo assim na Europa Ocidental os novos Estados Nacionais. Devido a ascensão econômica, fortalecem as Monarquias e as instituições políticas. Com isso desde os fins do século XIII, o Estado Absolutista apoiado sobre as classes médias, controlas a economia, sujeitando-se então a feudalidade e a igreja à sua autoridade.

O Estado Monárquico preserva seus privilégios e das classes superiores, mantendo a autoridade do Poder Central sobre a Burguesia, começa a nascer uma ideia de consciência politica no proletariado e nas massas rurais. As forças progressivas do desenvolvimento, do capitalismo, das navegações e a circulação geral do comércio expandem-se livremente. Dessa forma vemos que a economia desenvolve a força do Estado, ou seja, os interesses capitalistas coincidem com os do Estado Nacional e na sua oposição as forças descentralizadoras da economia urbana.

Enquanto a França e a Inglaterra confirmavam o Poder Monárquico, a Itália não conseguia a unificação de suas cidades, ainda no século XV. Cada cidade italiana assegurava o domínio do Mediterrâneo e dos empórios do Oriente. Surge o Tratado de $\operatorname{Lodi}^{10}$ (1453) põe fim a guerra de Milão e Florença contra Veneza, com isso o Papa, a Alemanha, a França e a Espanha disputam a supremacia política na península. No período do Renascimento a obra “O Príncipe” de Maquiavel é dominada pela ideia da unidade italiana.

Com a obra "O Príncipe", Maquiavel procura descrever e discutir as formas de governo mais apropriadas à sua preservação, apesar da transferência da forma em que é vazado, nada mais é do que uma espécie de "Manual do Absolutismo".

No século XVII pela primeira vez, Bayle ${ }^{11}$ emprega o termo maquiavelismo devido a sua forma de interpretar o livro "O Príncipe", foi erigido entranscedente problema de literatura política. O livro reflete as condições da época na qual e para a qual foi escrito. Mostrando a importância das reformas políticas, o livre exame dos fatos históricos, o ataque às tradições medievais, a instituição do êxito como medida do poder do príncipe, em fim, a ruptura do temporal com o espiritual.

\footnotetext{
${ }^{10}$ Foi um acordo de Paz entre os aliados de Milão (Florença. Mântua e Genoa) e os aliados da República de Veneza (Nápoles, Savoy e Montferrat), assinado em 4 de abril de $1454 \mathrm{em} \mathrm{Lodi,} \mathrm{Lombardia,} \mathrm{às} \mathrm{margens} \mathrm{do} \mathrm{rio} \mathrm{Adda.}$

11 (Bayle, Pierre (1647-1706), filósofo cético e enciclopedista francês, autor de "Dicionário Histórico e Crítico" (16961697), que editava também o influente jornal Nouvelles de la république des lettres ("Notícias da república das letras" - 16841687), afirmando em suas cartas sua independência dos cartesianos.).
} 
Artigo Original

Hegemonia - Revista Eletrônica do Programa de Mestrado em Direitos Humanos, Cidadania e Violência/Ciência Política do Centro Universitário Unieuro

ISSN: 1809-1261

UNIEURO, Brasília, número 27 (Especial), 2019, pp. 245-264.

Considerado o fundador da Ciência Política Moderna, Maquiavel começa a definir uma nova classificação de forma de governo, onde buscar o Poder e ter o Poder, se fazia necessário para se manter um Estado Absoluto. Com a frase "Todos os Estados que existem e já existiram são e foram sempre República (Aristocráticas /Democráticas) on Monarquia (Soberanas)", essa colocação de Maquiavel nos mostra o quanto ele tinha uma visão holística a respeito do que era uma República e o que era uma Monarquia.

Esse pensamento vem exatamente das ideais que tinha a respeito da teoria das formas de governo, formulada pelos gregos não tinha nascido nas cabeças dos filósofos, mas na observação das constituições das cidades Helènicas ${ }^{12}$, suas caraterísticas e mudanças. Tanto Platão como Aristóteles não podiam descrever sobre o principados ou república, pois eles nunca tinham vivenciado esse tipo de governo antes.

Maquiavel pode observar as formas de governo principado (reinado) dos regna por meio da Inglaterra, França e Espanha, que se tinham formado gradual depois da dissolução do Império Romano, alguns dos quais se vinham transformando nos grandes Estados territoriais que originaram o "Estado Moderno" e das civitates que se tinham expandido, dominando o território vizinho, inclusive outras cidades menores, e que eram governados por senhores temporários e eletivos ou por conselhos de notáveis ou de representantes.

$\mathrm{Na}$ época de Maquiavel, a Itália apresentava, na sua configuração geográfica as repúblicas de Gênova, de Veneza e a própria Florença. Em suas reflexões, pega os exemplos da República Romana e não as da Grega, a partir da República Romana, onde ele vai Descrever no Discurso sobre a primeira Década de Tito Ĺvio, o papel importante que teve esse período republicano da história secular e gloriosa, permitindo assim sua divisão entre a República e a Monarquia, confirmando então a tese de que os Estados são sempre Repúblicas ou Principados.

Um Estado bem ordenado, só pode ter uma constituição ou outra, cada uma das formas tem sua lógica. Se isso não acontece temos um Estado defeituoso, ou seja, não existe Estado Intermediário, o Principado só tem um caminho para sua dissolução, descer até a República e a República só tem um meio de dissolver-se; subir até o Principado.

Ainda considerando os Estados para Maquiavel os Estados Intermediários têm dois caminhos, um no sentido do Principado e outro no sentido da República, exatamente onde nasce a sua

\footnotetext{
12 Grécia - oficialmente República Helênica ou Helénica, é um país europeu localizado na parte meridional dos Bálcãs e confina a norte com a República da Macedônia, com a Bulgária, e com a Albânia, a leste com a Turquia, quer em fronteira terrestre, quer com fronteira marítima no mar Egeu, a sul com o mar Mediterrâneo e a oeste com o mar Jônico, pelo qual tem ligação com a Itália.
} 
Artigo Original

Hegemonia - Revista Eletrônica do Programa de Mestrado em Direitos Humanos, Cidadania e Violência/Ciência Política do Centro Universitário Unieuro

ISSN: 1809-1261

UNIEURO, Brasília, número 27 (Especial), 2019, pp. 245-264.

instabilidade, onde o pensador classifica como Maus Estados e ainda dentro dessas considerações, ele coloca que os Estados Estáveis são simples, ou seja, só pode ser Principados ou Repúblicas.

Ética e Política e a Ciência Política

Dentro de um contexto reflexivo o princípio ético, político e moral deveria fazer parte de uma política de Poder, onde está voltado para o estudo do jogo pela busca da estabilidade política e pela necessidade de segurança dos Estados novos que conquista com armas e virtudes. Maquiavel coloca que - "Um homem prudente mesmo seguindo a trilha aberta por outros deve saber que nunca alcançará o mesmo nível de virtude. Todo homem deve mostrar indícios das excelentes virtudes, mas deve deixar claro que tem horizontes e objetivos bem maiores".

Já ouvimos falar "os fins justificam os meios" uma variante de algo que ele diz no capítulo XVIII, também o adjetivo "maquiavélico" que já foi aplicado contra aqueles que a astúcia se supõe, justamente colidi com os imperativos da ética. No em tanto Maquiavel não sugeriu o uso popular desse adjetivo, como uma política sem ética, mas revolucionou o modo como tradicionalmente essa relação era pensada. Dessa forma podemos então tentar compreender a relação que se constitui essa revolução de ideia.

Antes de Maquiavel, tivemos o Tratado de De Regno (Do Reino) descrito por São Tomás de Aquino $^{13}$, onde ele compara o governo de uma república ao piloto de um navio, dizendo que “assim como cabe ao piloto do navio exercer duas funções - isto é: preservar o navio, evitando que ele afunde ou sofra avarias, e, além disso, conduzir o navio ao porto - do mesmo modo, cabe ao governante de uma República preservá-la, evitar que a vida pública se extinga, e, além disso, conduzi-la ao seu fim, fazer com que ela realize a finalidade que lhe cabe realizar".

Com esse pensamento São Tomás de Aquino traduz em uma finalidade ética. Então podemos concluir que; Cabe ao bom governante fazer dos homens que governa homens virtuosos, sendo a virtude o ponto ao qual o governante deve conduzir seus governados.

Por certo, pela visão de Maquiavel, cabe ao governante deixar a república intacta. Mas isso é tudo, nada mais se fala da finalidade da ética da política. Esse confronto de pensamentos era decorrente de que no tempo de Maquiavel, eram comuns os livros que traziam aconselhamento e ensinamentos aos governantes, é isso que faz São Tomás na sua obra e outros pensadores que remonta aos primeiros séculos da era cristã, e ainda muito presente no tempo de Maquiavel.

13 Foi um padre dominicano, filósofo, teólogo, distinto expoente da escolástica, proclamado santo e Doutor da Igreja cognominado Doctor Communis ou Doctor Angelicus pela Igreja Católica. 
Artigo Original

Hegemonia - Revista Eletrônica do Programa de Mestrado em Direitos Humanos, Cidadania e Violência/Ciência Política do Centro Universitário Unieuro

ISSN: 1809-1261

UNIEURO, Brasília, número 27 (Especial), 2019, pp. 245-264.

$\mathrm{Na}$ obra O Principe quem o consultasse, poderia esperar mais um manual de aconselhamento para o príncipe, mas na verdade a história era completamente outra, já que os manuais da época queriam somente explicar como um príncipe deveria fazer para ser um bom governante, a finalidade de governar bem era ser bom e governar mau era se afastar bem, daí usavam as usas obras para aconselhamento. Se esperava que Maquiavel também pretendesse dar conselhos, no entanto, nada se diz na obra $O$ Príncipe sobre a finalidade de governo, mas do que isso, ele abala o modo tradicional de se pensar entre o bom e o man governo, sugerindo modos de se fundar um principado e também em outras formas de se atuar no poder.

Maquiavel concebe a política de uma forma muito particular e inovadora comparando com São Tomás de Aquino que tinha uma visão harmoniosa entre a natureza o e homem. Mas as experiências vividas por Maquiavel dentro da política do poder fez com ele tivesse uma visão completamente diferente de São Tomás.

A experiência mostrava a Maquiavel que a vida social da época constituía sempre em um conflito entre dois grupos: os grandes e o povo. O que define os grandes é o que deseja governar e oprimir o povo e o que define o povo e o que deseja não ser governado e oprimido pelos grandes. "Em todas as cidades se encontram estas duas tendências diversas", escreve Maquiavel no capítulo IX de "O Príncipe", que indica que ele concebe essa posição como constitutiva da vida política.

Para Maquiavel a arte de governar consiste o bom termo entre este conflito, o que não expressa suprimi-lo, pois, visto que ele claramente percebe que está presente em todas as cidades italianas.

Cabe ao príncipe institucionalizar o conflito, possibilitando o convívio e mutua cooperação das partes conflitantes. As instituições da antiga república romana, com seu sistema de participação alternada das decisões políticas faziam isso muito bem, segundo Maquiavel. Com essa de intensão de mostrar que ele as analisa detidamente nos seus Discursos sobre a Primeira Década de Tito Livio.

A vida social é para Maquiavel um campo de forças e só pode prosperar se essas forças de algum modo se equilibram. Eis assim o papel do governante: procurar e até mesmo forçar, se necessário, esse equilíbrio, contentando ora uma parte, ora outra, fazendo com que ora um, ora outro seja obrigado a ceder, de modo que todos tenham o seu desejo em parte, mas nunca totalmente realizado. Era importante esse equilíbrio interno pois do contrário, a parte conflitante insatisfeita iria recorrer a forças estrangeiras fazendo valer seus interesses, algo que era muito comum da Itália daquele tempo.

Segundo Maquiavel no lugar de resolver os conflitos internos a Itália acabava em uma situação de extrema vulnerabilidade política á mercê das forças políticas externas, tratava-se desse 
Artigo Original

Hegemonia - Revista Eletrônica do Programa de Mestrado em Direitos Humanos, Cidadania e Violência/Ciência Política do Centro Universitário Unieuro

ISSN: 1809-1261

UNIEURO, Brasília, número 27 (Especial), 2019, pp. 245-264.

modo, resolver os conflitos internos para conquistar uma posição forte perante as forças políticas externas. Dessa forma um Estado pode perdurar, mas Roma antiga, as instituições republicanas desempenhavam esse papel, e com o tempo essas instituições se perderam.

Para Maquiavel, entendia ele que, à época dele, na Itália do século XVI, a melhor solução dos conflitos que geravam tantas guerras e tornavam tão instável a vida política italiana consistia no apelo à capacidade conciliatória, não mais das instituições republicanas, mas das ações de um príncipe que se colocasse entre os grandes e o povo, mediando à disputa entre eles.

No livro "O Principe", Maquiavel aconselha ao governante que ele deve fazer exatamente aquilo que as instituições da Roma antiga faziam; retirando a sua força política e sua capacidade de governo em parte do apoio dos grandes, e em parte do apoio do povo, para ele governar, isto é, preservar a vida comum fortalecer-se internamente contra as foças estrangeiras.

Originalmente segundo o pensamento de Maquiavel os conflitos estão na base da política, e cabe a ela, política, mediar os conflitos sociais e também reside para ela toda a dificuldade da arte de governar. Até então, ninguém antes havia pensado assim, ou seja, pensar a política sem relacioná-la à questão dos conflitos que é estruturante da vida social e insuperável.

Não é apenas porque o governante já se encontra ocupado em mediar conflitos que ele pode se desincumbir da ação de governar, de tornar os homens virtuosos. Isso não significa que os governantes não têm tempo para cuidar da virtude de seus governados, mas mostrar que essa, decididamente, não é e nem pode ser a sua função. Quando se trata a respeito da sua qualidade ética, o governante é um homem comum, com seus interesses e opiniões particulares, não melhores nem mais nobres que as dos outros homens a quem governa.

São Tomás pensava o governante quase como um santo, um modelo de virtude. As mesmas qualidades que o capacitavam a fazer com que sua alma governe o seu corpo como é devido, habilitam-no a governar bem a sua familia e a governar bem a sua República. Suas qualidades públicas, aquelas que o faziam dele um bom governante, eram assim entendidas como um prolongamento de suas capacidades privadas, que o tornavam um homem bom. Pois era precisamente por saber como governar a si próprio que se entendia que o governante se qualificava para governar outros, isto é, conduzi-los à virtude (virtú) ${ }^{14}$, segundo o modo como então se compreendia a arte de governar.

Mas Maquiavel, por entender de outro modo essa arte, concebia as qualidades do governante como qualidades específicas de sua função; as qualidades de um homem público, que se distingue dos outros não em virtude de sua excelência privada, mas em virtude de sua capacidade

${ }^{14}$ Virtù seria a capacidade de adaptação aos acontecimentos políticos que levaria à permanência no poder. A virtù seria como uma barragem que deteria os desígnios do destino. 
Artigo Original

Hegemonia - Revista Eletrônica do Programa de Mestrado em Direitos Humanos, Cidadania e Violência/Ciência Política do Centro Universitário Unieuro

ISSN: 1809-1261

UNIEURO, Brasília, número 27 (Especial), 2019, pp. 245-264.

de articular as forças sociais. Embora o que distingue o governante dos outros homens não seja a sua excelência ética, se por isso entendemos certas qualidades privadas. Em umas das passagens de $O$ Principe, Maquiavel afirma que convém ao governante parecer ter essa excelência, uma que os homens esperam e supõem que eles sejam pessoas eticamente superiores, só se deixando governar por quem assim lhes pareça.

Podemos dizer que cabe ao governante maquiaveliano ${ }^{15}$ não mais aplicar uma regra de justiça, mas inventar, instituir uma regra que pareça satisfatória àqueles a quem governa. O pensamento do filósofo colocou um conflito ético e político e ao mesmo tempo tentando entender que a virtude do político consiste em saber mediar conflitos, permitir acordos e a partilha de valores comuns, logo, na razão de Maquiavel, ética e política são incompatíveis e se entende que seria impossível atribuir uma ética a política.

Essa ética é precisamente o que Maquiavel chamou de virtú, a virtude política e cívica, e que consiste na capacidade de criar e respeitar as instituições necessárias do convívio comum.

A ética de Maquiavel se contrapõe à ética cristã herdada por ele da idade média, para a ética cristã as atitudes dos governantes e dos Estados estavam subordinados a uma lei superior e a vida humana destinados a salvação da alma. Já para Maquiavel a finalidade das ações passa a ser a manutenção da prática e o bem geral da comunidade, não o próprio, mas de forma que uma atitude não pode ser chamada de boa ou má a não ser sob uma perspectiva histórica.

Maquiavel e sua obra central

Nessa obra podemos observar que Maquiavel coloca todas as formas de governo em que ele acha conveniente por em prática a partir do momento em que se encontra um Estado. Vamos ver de quantas espécies são os principados e de quantos modos se adquirem, eles podem ser hereditários, cujo senhor é príncipe pelo sangue, por longo tempo, ou seja, o Poder é transmitido com base numa lei constitucional de uma sucessão, ou são novos, são como membros acrescentados a um Estado que um príncipe adquire por herança, onde o Poder é conquistado por quem ainda não "era” um príncipe.(Francisco Sforza ${ }^{16}$ de Milão)

Antes de colocarmos essas teorias, ou seja, as formas de governo, vamos dividir " $O$ Príncipe" em duas grandes partes: a primeira vai do capítulo I ao XIV, onde Maquiavel trata dos

\footnotetext{
15 Evitando utilizar o termo "maqioavélico" de tom um tanto negativo.

${ }^{16}$ Francisco II Sforza ou Francisco Maria Sforza (Milão, 4 de fevereiro de 1495 - Vigevano, 24 de outubro de 1535 ) foi o último Duque independente de Milão, cargo que ocupou desde 1521 a 1535.
} 
Artigo Original

Hegemonia - Revista Eletrônica do Programa de Mestrado em Direitos Humanos, Cidadania e Violência/Ciência Política do Centro Universitário Unieuro

ISSN: 1809-1261

UNIEURO, Brasília, número 27 (Especial), 2019, pp. 245-264.

diversos tipo de principados, do modo de conquista-los e mantê-los, dando principal preferência aos principados novos, onde ele exibe um certo aspecto do poder político que lhe interessa ressaltar, dando ênfase "a força como elemento constitutivo do poder político". Tal força seria aplicada a partir do momento em que o governante poderia recorrer ao falhar nos recursos regulares de governo, tais como a persuasão e o exemplo de sua própria virtude.

Essa força é mostrada constantemente ao longo dessa primeira parte da obra, onde um príncipe tem "a necessidade de ofender", essa necessidade vem do fato de que o príncipe, sendo um mediador de conflitos, não pode agradar a todos em todos os momentos, sendo assim preciso forçar certas condutas e vencer as resistências.

A segunda parte fecha do capítulo XV ao XXVI, onde ele vai discorrer sobre "como deve se comportar um príncipe com os súditos ou com os amigos", ou seja, nessa segunda parte trata-se do modo como o príncipe deve parece às outros homens, isto significa que para Maquiavel "a aparência" seria importante como revestimento para o portador desse poder.

Podemos então citar duas formas dadas para o principado hereditário, onde um príncipe e seus assistentes na qualidade de ministro, o ajudam a administrar o país agindo por sua graça e licença, e a outra forma seria quando um príncipe tivesse vários barões, cuja posição, não se explica por um favor do soberano, mas pela antiguidade da própria família.

Além das formas podemos também perceber que apresentam duas espécies de príncipes hereditários, o que governa sem intermediário, cujo Poder é absoluto e seus súditos são os seus servos e o outro governa com intermediação da nobreza, cujo Poder é original não dependendo do Rei, mas esse Poder não é absoluto porque é dividido com os barões, embora guarde uma posição superior.

Partindo desses princípios colocados por Maquiavel, tanto ele quanto Aristóteles vão conceituar esses comportamentos de principados hereditários como Monarquia Despótica - na qual a relação entre dominante e dominado é semelhante ao que existe entre o Senhor e o Servo, dando como exemplo o próprio governo da Turquia, considerado como Despotismo Oriental. Esse conceito persistirá até Hegel ${ }^{17}$.

No pensamento de Maquiavel os principados novos vão apresentar na maioria do discorrer da obra, ele vai distinguir quatro formas de se conquistar o poder; pela virtú, pela fortuna, pela violência e com o consentimento dos cidadãos. Podemos observar que essas quatro formas de conquistas podem se dispor de dupla ligação, onde teremos virtú-fortuna e força-consentimento.

${ }^{17}$ Hegel foi um dos criadores do idealismo alemão e naturalmente da génese do que é chamado de hegelianismo. 
Artigo Original

Hegemonia - Revista Eletrônica do Programa de Mestrado em Direitos Humanos, Cidadania e Violência/Ciência Política do Centro Universitário Unieuro

ISSN: 1809-1261

UNIEURO, Brasília, número 27 (Especial), 2019, pp. 245-264.

Para a concepção maquiaveliana os conceitos de virtú (coragem, valor, capacidade e eficácia política) e de fortuna (sorte, acaso, influência das circunstâncias), tem grande importância dentro do contexto histórico. Ele entende que virtú seria a capacidade pessoal de dominar os eventos, de alcançar um fim objetivado, por qualquer meio e a fortuna o curso dos acontecimentos que não dependem da vontade bumana. Para Maquiavel dependendo das circunstâncias e do momento histórico vai depender de ambos os fatores.

Existem diferenças entre uma conquista pelo principado virtú e pela fortuna, onde o primeiro são mais duradouros e o segundo são conquistados devido as circunstâncias favoráveis e não pelo próprio mérito, por isso são menos estáveis podendo desaparecer em pouco tempo.

Em se tratando dos principados conquistados pela violência - per scelera, Maquiavel tem uma opinião muito clara sobre essa forma de principado em que não introduz a distinção entre principados bons e maus, entre príncipe e tirano ele distingue os vários tipos de principados de acordo com o modo da sua aquisição, isso quer dizer que, aquele que chega a dominar um principado per scelera corresponde a figura do Tirano Clássico, mas para ele é um príncipe como os demais.

Os príncipes novos que conquistaram o poder pelo sua virtú são celebrados como fundadores do Estado e considerados como grandes protagonistas da história de seu país, onde Hegel chamará de indivíduos cosmo históricos e, por conseguinte Max Weber construirá a figura do chefe carismático. Príncipe que conquista o Estado "per scelera" é diferente, pois, é o tirano no sentido tradicional.

Em se tratando da boa ou má política podemos distingui-la como a forma de êxito em que no caso do príncipe novo o êxito na política é medido pela capacidade de manter um Estado estável, onde Maquiavel procura manter o critério de comparação desse êxito entre um tirano bom e o man dentro da categoria dos Tiranos Celerados. O Tirano bom é aquele que, como Agátocles, embora tenha conquistado o poder por meios criminosos, consegue depois mantê-lo. Mau é Liverotto de Fermo, que só se manteve no poder durante um ano, após seu mandato teve o mesmo fim miserável que havia dado aos seus adversários.

Sobre essas observações comenta Maquiavel:

"Penso que depende da crueldade bem ou mal empregada". Os dois príncipes foram cruéis, mas a crueldade de um deles foi bem utilizada, tendo em vista seu objetivo a única coisa que conta na atividade política. A crueldade do outro não serviu ao único fim que deve orientar todas as ações de um príncipe; a manutenção do poder. “... a diferença reside no uso adequado ou não da crueldade. No primeiro caso, estão aqueles que a usaram bem uma vez só, com o objetivo de se garantir, e que depois não persistiram nela, mas ao contrário a substituíram por medidas tão benéficas 
Artigo Original

Hegemonia - Revista Eletrônica do Programa de Mestrado em Direitos Humanos, Cidadania e Violência/Ciência Política do Centro Universitário Unieuro

ISSN: 1809-1261

UNIEURO, Brasília, número 27 (Especial), 2019, pp. 245-264.

a seus súditos quanto possível. As crueldades mal empregadas são as que, sendo a princípio poucas, crescem com o tempo, em vez de diminuir. Os que aplicam o primeiro método podem remediar de alguma forma sua condição, diante de Deus e dos homens, como Agátocles. Quanto aos outros, não conseguem se manter". (cap. VIII)

O princípio maquiaveliano para traduzir a frase: "os fins não justificam os meios" é simplesmente para mostrar que todo príncipe deve manter o poder independente das circunstâncias. O julgamento sobre a bondade ou a maldade de um príncipe não se faz com base nos meios que emprega, mas exclusivamente com base no resultado que obtém qualquer que sejam os meios usados. Assim diz Maquiavel:

“... na conduta dos homens, especialmente dos príncipes, da qual não há recurso, os fins justificam os meios. Portanto, se um príncipe pretende conquistar e manter um Estado, os meios que empregar serão sempre tidos como honrosos, e elogiados por todos, pois o vulgo se deixa sempre levar pelas aparências e os resultados; ..."(cap. XVIII)

Para o fechamento desse capítulo, podemos descrever a importância do pensamento de Maquiavel com um olhar apaixonante e nacionalista de um florentino que busca em suas colocações a forma de governo ideal para seu país naquele momento. Isso se expressa nitidamente no capítulo XXVI, onde ele coloca que a Itália está ainda à espera do seu Moisés, do seu Ciro, do seu Teseu, mostrando então a busca de uma unificação e fundação da nova identidade italiana, onde não poderá deixar de ser levada a termo senão por meio da ação decidida e da disposição aos sacrifícios maiores que são próprios de toda guerra, inclusive das liberdades.

Para mostrar a visão holística desse filósofo, podemos citar também as duas grandes obras que vem complementar esse trabalho magnífico que foi "O Principe", trata-se de o Discorsi Comentários sobre a Primeira Década de Tito Livio e A Arte da Guerra, em que se Maquiavel dá continuidade aos propósitos de se conquistar, manter e defender um Estado.

Repúblicas e Formas de Governo

Podemos dizer que quando Maquiavel começou a escrever "O Príncipe", ele já tinha escrito o primeiro livro I dos Discorsi, e deixa muito claro que na primeira obra as questões políticas são voltadas para o "príncipe novo"(ou governante) e na segunda procura avaliar o quadro social na sua totalidade e ofereça 
Artigo Original

Hegemonia - Revista Eletrônica do Programa de Mestrado em Direitos Humanos, Cidadania e Violência/Ciência Política do Centro Universitário Unieuro

ISSN: 1809-1261

UNIEURO, Brasília, número 27 (Especial), 2019, pp. 245-264.

uma visão global do sistema político como uma república, alicerçando assim as fundações de sua teoria na res publica.

Os Discorsi são divididos em três livros: no primeiro Maquiavel trata do funcionamento interno das repúblicas; no segundo abordas principalmente questões militares e no terceiro discute a ascensão e queda das repúblicas, isto é, da dinâmica dos Estados. Essa obra Maquiavel se limita a discorrer sobre a constituição de Roma e também mostrar que no período de Tito Lívio ${ }^{18}$, onde na verdade podemos considerar que Maquiavel se inspira em Políbio ${ }^{19}$, principalmente quando ele fala também da própria Roma e sua república.

Em descrevendo sobre as formas políticas de governo de Roma e Esparta, Maquiavel praticamente segue os passos de Políbio quando retrata os três temas de formas de governo: a tipologia clássica das seis formas de governo, a teoria dos ciclos e a do governo misto, onde o primeiro recebeu sua constituição e um legislados e a segunda de uma tradição gradual de forma natural, enriquecendo os comentários sobre a constituição romana esboçando historicamente a descrição do surgimento do Estado, a partir de uma fase primitiva, quando os homens viviam "dispersos, à semelhança dos animais".

A tipologia maquiaveliana traduz as três formas de governo e suas seguintes consequências:

"... lembrarei que há três espécies de governo: o monárquico, o aristocrático e o popular; os que pretendem estabelecer a ordem numa cidade devem escolher, dentre estas três espécies, a que melhor convém a seus objetivos. Outros, segundo a opinião geral os mais esclarecidos, acham que há seis formas de governo, das quais três são essencialmente más; as três outras são em si boas, mas degeneram tão facilmente que podem também tornar-se perniciosas. Os bons governos são os que relacionei anteriormente; os maus, suas derivações. E se parecem tanto aos primeiros, aos quais correspondem, que podem com facilidade ser confundidos com eles. Deste modo, a monarquia se transforma em despotismo; a aristocracia, em oligarquia; a democracia, em permissividade. Em consequência, todo legislador que adota para o Estado que vai fundar uma destas três formas de governo não a mantém por muito tempo; não há o que apossa impedir

\footnotetext{
${ }^{18}$ Conhecido simplesmente como Lívio, é o autor da obra histórica intitulada Ab urbe condita ("Desde a fundação da cidade"), onde tenta relatar a história de Roma desde o momento tradicional da sua fundação 753 a.C. até ao início do século I da Era Cristã, mencionando desde os reis de Roma, tanto os primeiros como os Tarquínios.

19 Foi um geografo e historiador da Grécia Antiga, famoso pela sua obra "Histórias", cobrindo a história do mundo Mediterrâneo no período de 220 a.C. a 146 a.C.. É-lhe também atribuída a invenção de um sistema criptográfico de transliteração de letras em números.
} 
Artigo Original

Hegemonia - Revista Eletrônica do Programa de Mestrado em Direitos Humanos, Cidadania e Violência/Ciência Política do Centro Universitário Unieuro

ISSN: 1809-1261

UNIEURO, Brasília, número 27 (Especial), 2019, pp. 245-264.

de precipitar-se no tipo contrário, tal a semelhança entre a forma boa e a má...” (cap. II)

Do ponto de vista terminológico, vale observar que dos termos gregos originais, só permaneceu "tirania", todos os outros são palavras latinas: principado, governo de poucos, governo popular licencioso e permissivo. Dessa forma Maquiavel vai descrever que as constituições das três formas de governo boas se corrompem com tal facilidade que podem também tornar-se perniciosas, dessa forma podemos considera-las como despóticas, oligárquicas e permissivas.

Quando Maquiavel coloca essas formas de governo perniciosas, ele as descreve como sendo as despóticas sendo constituída naturalmente a partir de uma agregação inicial que permite reconhecer uma liderança autocrática, é a Monarquia. O primeiro ponto a ressaltar é, portanto, que a forma original do Poder se constitui não pela Força, pela diferenciação da Força. Tanto Maquiavel quanto Polibio concordam que a constituição do Poder aparece como anterior a Moral, e essa moralidade passa pela percepção dos sentimentos, até aqui passando por uma constituição de vida comum, o que se faz comumente com base num comando de Força.

A degeneração da Monarquia conduz a tirania (ou despotismo) e o que leva a Monarquia à corrupção é a possibilidade de que o princípio de hereditariedade possa não ser suficiente para garantir a manutenção das condições de legitimidade. Já a instituição da Aristocracia, supõe-se que a revolta contra a tirania responde a uma necessidade dos súditos, mas só vai se concretizar a partir do meio de liderança dos melhores, ou seja, é naturalmente constituída por aqueles que assumem a liderança na resistência a tirania.

Com a perda da legitimidade da Aristocracia em razão das mesmas causas citadas anteriormente, corrompe-se numa Oligarquia passando então para o chamado Governo Popular, que por sua vez, se degenera em Anarquia fazendo fechamento do ciclo e retornando ao início do processo político. Todo esse processo político Maquiavel o chama de aquisição e perda da legitimidade. Quando se perde os valores que fundamentam certas formas de governo ou seu conteúdo, perdese a legitimidade, logo irão se degenerar com o passar do tempo. Se todas as formas de governo boas ou más, estão sujeitos a esse ciclo de aparecimento e decadência concluído que mesmo as formas boas ou legítimas são defeituosas ou imperfeitas, pois não são duráveis.

Acrescentando suas ideias aos pensamentos de Políbio, Maquiavel coloca que - "a noção de que a liberdade e a força da república romana teria nascido da desunião entre a plebe e o Senado", mostrando 
Artigo Original

Hegemonia - Revista Eletrônica do Programa de Mestrado em Direitos Humanos, Cidadania e Violência/Ciência Política do Centro Universitário Unieuro

ISSN: 1809-1261

UNIEURO, Brasília, número 27 (Especial), 2019, pp. 245-264.

assim, que contra a tradição, a ideia do conflito como condição de estabilidade e/ou firmeza da república, pode definir assim uma república firme ou não. Descreve então Maquiavel:

"Toda as leis para proteger a liberdade nascem da desunião entre o povo e os poderosos, entre a plebe e o Senado". (cap. IV)

Então podemos dizer que nessa perspectiva, as leis são postas em segundo plano uma vez que resultam do conflito, isto é, o povo não age contra os grandes senão pelo desejo de não ser oprimido. No raciocínio de Maquiavel, as leis oferecem um certo mecanismo de acomodação dos conflitos constituindo assim meios para institucionalizar os conflitos numa sociedade. As leis constituem um meio de emprego a força, ou seja, a força vai ser utilizada de modo mais econômico quando a república dispuser de leis capazes de diminuir e controlar as tensões sociais.

A força é sempre um recurso importante, mas as leis devem limitar seu emprego. Podemos ver como exemplo dois fatos ocorridos; um relacionado ao recurso a força estrangeira como ocorreu em Florença e a outra em Roma quando perdeu a capacidade de acomodação institucional dos conflitos, mostrando assim a ineficiência institucional do Estado. Por isso uma crise de governo, uma crise política não acarreta necessariamente a crise institucional ou do Estado. A institucionalização de um tal poder gera dois efeitos de relevo para a república: os cidadãos, temendo ser acusados, não ousam investir contra a segurança do Estado e o outro ele constitui uma espécie válvula de escape à paixão que sempre fermenta contra algum cidadão.

Não podemos de citar a influência da igreja no processo político formador de uma república. Quando as leis e os comandos oriundos da boca de um fundador de Estados, sejam elas repúblicas ou reinos/principados vierem associados às palavras de fundadores de religiões, tanto mais eficaz será o seu comando e mais forte a sua vontade. As normas da religião obrigam com maior força do que as leis positivas, gerando normas de comportamento fidedignas que funcionam mesmo quando há possibilidade de violação da lei. É parte da ação política prudente manter e valorizar a crença religiosa, diz Maquiavel, e continua, pois ela fortalece a fidelidade ao Estado e a união entre os cidadãos.

Quando Maquiavel comenta Os Discorsi, procura mostrar que a res pública só é perfeita a partir de um processo político entre o ceder e o cobrar, se isso não for bem feito torna-se trágico e ao mesmo tempo acaba se perdendo como ocorreu com Roma. A expansão dessa tão grandiosa e duradoura república só poderia ocorrer no momento em que sua política estivesse fincada numa 
Artigo Original

Hegemonia - Revista Eletrônica do Programa de Mestrado em Direitos Humanos, Cidadania e Violência/Ciência Política do Centro Universitário Unieuro

ISSN: 1809-1261

UNIEURO, Brasília, número 27 (Especial), 2019, pp. 245-264.

estratégia de amenizar as vontades do povo e conciliá-las com o uso da força por parte do Estado. Sendo assim, Maquiavel descreve nessa obra as questões das conquistas além fronteiras, para que os direitos envolvidos politicamente entre o poder e o povo, fossem resolvido de forma de ambos os interesse, caso contrário poderiam então se agravar e instituir ali uma guerra política.

Em circunstâncias como essas, dizia Maquiavel: "não há como deixar de evoca as palavras de Tito Livio aos quais relatava - Justas, pois, são as guerras necessárias, e piedosas as armas quando só nelas há esperança”. Sendo assim, via ali Maquiavel, que um Estado forte e poderoso não poderia deixar de ter um exército a sua altura, não só, para proteger o Estado e suas fronteiras, mas também para que o povo percebesse o quanto estariam seguros dentro de seus territórios.

Então Maquiavel só se tornou Maquiavel, quando pode fazer-se pensador da política pura na medida em que se recusou, terminantemente a tratar da política e das questões políticas como questões éticas, passando então a ter uma visão e uma atenção privilegiada voltada para as questões militares, trazendo na obra A Arte da Guerra, a importância de se ter um exército consistente e a presença sempre maximamente próxima do exercício da força e da violência como dimensão incontornável da conquista, da manutenção e da preservação do poder político.

A Arte da Guerra é um tratado de estratégia militar, desdobrado de maneira sistemática e com minúcia obsessiva. Do ponto de vista metodológico, Maquiavel coloca a importância de se pensar a problemática militar dos modernos à luz das lições dos antigos, notadamente dos romanos, os quais, como ninguém, foram capazes de organizar-se militarmente. Como essa obra é dividida em sete livros, cabe aqui apenas descrever o pensamento do nosso filósofo político as formas de organização militar em suas estratégias, formações, suas unidades, armamentos, conduta militar e instalações militares.

No contexto da obra podemos perceber que Maquiavel havia pensado em todos os aspectos de se manter uma república estável e segura e ao mesmo tempo mostrar que todo Estado forte depende também de um bom exército, estrategicamente bem aparelhado, estruturado humanamente e consistente em suas aplicações militares. Para se estabelecer uma república estável, o governante deve selecionar seus melhores soldados a partir de jovens aguerridos e homens dispostos a defender suas terras dos estrangeiros, pois só assim, por meio de um corpo militar fortemente armado e voltado para as questões intitulada nacionalidade, se pode então se resguardar suas propriedades. 
Artigo Original

Hegemonia - Revista Eletrônica do Programa de Mestrado em Direitos Humanos, Cidadania e Violência/Ciência Política do Centro Universitário Unieuro

ISSN: 1809-1261

UNIEURO, Brasília, número 27 (Especial), 2019, pp. 245-264.

Conclusões

A Arte da Ciência Política consolidada por Nicolau Maquiavel teve e tem grande importância para a formação do pensamento político do Estado, nestes últimos séculos até o mundo atual. Ao retratar nas suas obras questões de formas de governo, estratégias políticas, organizações militares e até mesmo questões religiosas, podemos notar a visão extraordinária deste cientista.

Vivendo num momento conturbado em seu país, Maquiavel se volta para as questões políticas internas e ao mesmo tempo, procura relacionar a sua vivência como diplomata em suas colocações nas obras citadas. Dentro desse contexto vimos que a Itália ainda não tinha se definido como um Estado politicamente estabelecido, isso porque, as ideias políticas e formas de aplicação das leis estavam voltadas para os interesses individuais daqueles que achavam convenientes e adequados para o momento.

Convém lembrar que, muito embora a grandeza e o prestígio incomparável de Maquiavel se derivem em grande e decisiva medida de seu inédito modo de isolar o fenômeno do poder e de analisa-lo iminentemente, sem as distorções que a associação das questões de poder às questões éticas não pode deixar de mostrar com muitas propriedades os exemplos voltados para os Estados que deram certo e que, na verdade, era exatamente o que ele gostaria para a sua Itália.

A busca incessante pela perfeita harmonia do poder de Estado aplicado pelos governantes e respondido pelos cidadãos italianos, mostra a cada obra, a necessidade de se ter como forma política a presença do poder firme seguido de astúcia para controlar os ímpetos do povo a ser governado. Maquiavel coloca muito bem esse fato a partir do momento em que exemplifica a república romana em dos Discorsi, procurando mostrar o quanto é importante se ter o controle e o poder ao mesmo tempo.

De fato, diante de todos os aspectos em que se mostraram as ideias de Maquiavel, podemos então fazer uma análise de que na Itália ainda dividida entre república e principado e também pelas constantes trocas de poder, seria necessário uma grande reforma política, sendo essa a principal meta do filósofo florentino na vivência enquanto teve envolvido nas questões políticas de seu país e principalmente quando se resguardou em retiro e exílio para aí sim colocar todas as suas ideias visionárias dentro das questões políticas, públicas, militares e civis.

Como cidadão de Florença e com sua visão política holística, Maquiavel procurou mostrar em suas obras o quanto a Ciência Política pode contribuir para a paz e a felicidade. Não se conforma com impotência e a decadência italiana, com a ausência de um Estado nacional e com as humilhações que daí decorrem mais do que todo, a submissão repetida das questões italianas à 
Artigo Original

Hegemonia - Revista Eletrônica do Programa de Mestrado em Direitos Humanos, Cidadania e Violência/Ciência Política do Centro Universitário Unieuro

ISSN: 1809-1261

UNIEURO, Brasília, número 27 (Especial), 2019, pp. 245-264.

influência e à vontade das grandes potências, notadamente Espanha, França e Inglaterra com inusitada paixão, o sentimento patriótico e de sua esperança de que a Itália um dia possa ser palco de um segundo renascimento, do renascimento de si mesma como unidade e potência política.

\section{Referência Bibliografia}

AQUINO, São Tomás. O Pensamento Político de São Tomás de Aquino “ De Regno Ad Regem Cupri”. José Urbano de Lima Júnior, Universidade Católica de Pernambuco, Instituto de Teologia de Caruaru, Dissertatio, Revista de Filosofia, no 12, UFPel, pp. 1-146, Versão de 2000.

BIGNOTTO, Newton. Maquiavel republicano. São Paulo: Loyola, 1991.

BOBBIO, Norberto. Teoria geral da política. Rio de Janeiro: Campus, 2000.

BOBBIO, Norberto. A teoria das formas de governo. Tradução de Sérgio Bath, Brasília, Editora Universidade de Brasília,1980, 10ª ed.

KRITSCH, Raquel. Maquiavel e a República: lei, governo legal e institucionalidade política nos Discursos sobre a primeira década de Tito Lívio, Revista Espaço Acadêmico, no 113, Outubro de 2010 - Mensal - Ano X - ISSN 1519-6186.

Maquiavel, Nicolau. O Príncipe. Tradução, Prefácio e Notas de Lívio Xavier, Rio de Janeiro, Ediouro, 2002, 36ª ed.

Maquiavel, Nicolau. O Príncipe. Tradução e Notas de Henrique Amat Rêgo Monteiro, São Paulo, Clio Editora, 1012. $2^{\mathrm{a}}$ ed.

MAQUIAVEL, Nicolau. A Arte da Guerra. Tradução e notas de Eugênio Vinci de Morais, Editora L\&MP Pocket, 2007.

MAQUIAVEL, Nicolau, 1469-1527. Comentários sobre a primeira década de Tito Lívio. Tradução de Sérgio Bath, Brasília, Editora Universidade de Brasília, 1994, $3^{a}$ ed. 